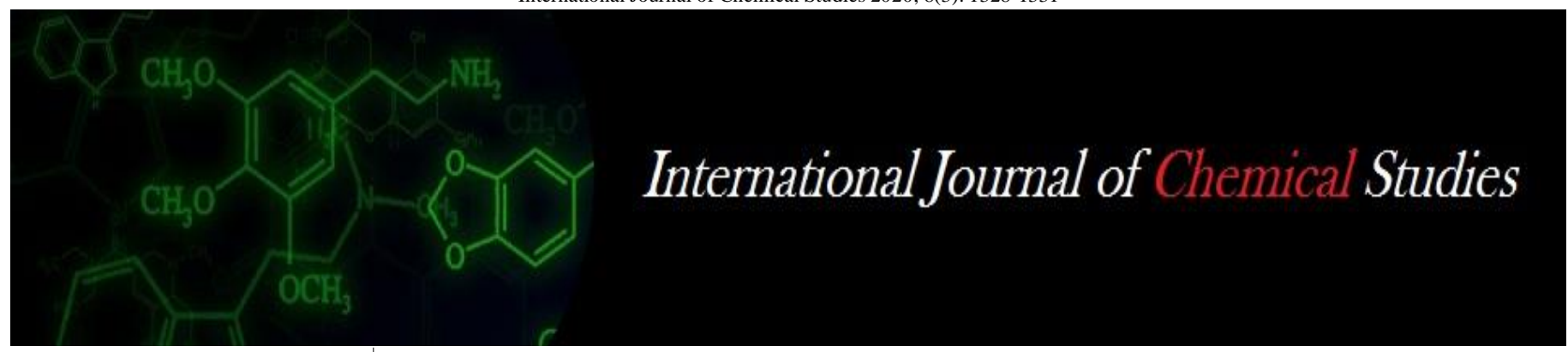

P-ISSN: 2349-8528

E-ISSN: 2321-4902

www.chemijournal.com

IJCS 2020; 8(3): 1328-1331

(C) 2020 IJCS

Received: 14-03-2020

Accepted: 16-04-2020

\section{Syeda Farwah}

Division of Vegetable Science,

Sher-e-Kashmir University of

Agricultural Sciences \& Technology

of Kashmir, Shalimar, Srinagar,

Jammu \& Kashmir, India

\section{K Hussain}

Division of Vegetable Science,

Sher-e-Kashmir University of

Agricultural Sciences \& Technology

of Kashmir, Shalimar, Srinagar,

Jammu \& Kashmir, India

\section{Seerat Rizvi}

Division of Vegetable Science, Sher-e-Kashmir University of Agricultural Sciences \& Technology of Kashmir, Shalimar, Srinagar, Jammu \& Kashmir, India

\section{Syed Mazahir Hussain}

Division of Vegetable Science,

Sher-e-Kashmir University of

Agricultural Sciences \& Technology

of Kashmir, Shalimar, Srinagar,

Jammu \& Kashmir, India

Majid Rashid

Division of Vegetable Science,

Sher-e-Kashmir University of

Agricultural Sciences \& Technology

of Kashmir, Shalimar, Srinagar,

Jammu \& Kashmir, India

Sana Saleem

Division of Vegetable Science,

Sher-e-Kashmir University of

Agricultural Sciences \& Technology

of Kashmir, Shalimar, Srinagar,

Jammu \& Kashmir, India

\section{Corresponding Author:}

Syeda Farwah

Division of Vegetable Science,

Sher-e-Kashmir University of

Agricultural Sciences \&

Technology of Kashmir,

Shalimar, Srinagar, Jammu \&

Kashmir, India

\section{Genetic variability, heritability and genetic advance studies in chilli (Capsicum annuum $\mathrm{L}$.) genotypes}

\author{
Syeda Farwah, K Hussain, Seerat Rizvi, Syed Mazahir Hussain, Majid \\ Rashid and Sana Saleem
}

DOI: https://doi.org/10.22271/chemi.2020.v8.i3r.9383

\begin{abstract}
Genetic variability, heritability, genetic advance and genetic advance as a percent over mean for twenty two characters were assessed by field evaluation of sixty chilli genotypes at the Experimental Field, Division of Vegetable Science, SKUAST-K, Shalimar during Kharif 2018. The experiment was laid out in randomized complete block design (RCBD) with three replications. High degree of variation was observed for all characters. The difference between phenotypic coefficient of variation and genotypic coefficient were found to be narrow for most of the traits. The high estimates of heritability was found for number of fruits plant ${ }^{-1}(99 \%)$, fruit length $(96 \%)$, fruit diameter $(68 \%)$, fruit weight $(95 \%)$, number of fruits plant ${ }^{-1}(99 \%)$, and fruit yield plant ${ }^{-1}(99 \%)$.
\end{abstract}

Keywords: Variability, heritability, genetic advance, PCV, GCV

\section{Introduction}

Chilli (Capsicum annuum L.) $(2 \mathrm{n}=2 \mathrm{x}=24)$ belongs to the family Solanaceae (Nightshade). The genus name Capsicum is derived from the Latin word 'capsa' meaning chest or box because of the shape of fruit which encloses seeds very neatly, as in the box. It is native of Tropical America and West Indies and is believed to have been introduced to India by the Portugese in the seventeenth century. Since then it has gained importance as an inevitable condiment and vegetable. Its production and consumption has steadily increased worldwide during $20^{\text {th }}$ century due to its use as both vegetable and spice and is an important component of diverse cuisines in the world. It is the leading spice-cum-vegetable crop grown commercially throughout the world. Its fruit appear in different shapes, sizes and colours. It is highly valued for its green or red ripe fruits with characteristic pungency, colour and flavour. It is consumed as fresh, dried or in powder form (El-Ghoraba et al., 2013; Pujar et al., 2017) ${ }^{[5,21]}$. The fruits are an excellent source of health-related phytochemical compounds, such as vitamin $\mathrm{C}$ $(143.7 \mu \mathrm{g})$, vitamin A $(292.04 \mathrm{IU})$ vitamin E $(0.69 \mathrm{mg})$, vitamin $\mathrm{K}(14 \mu \mathrm{g})$ per $100 \mathrm{~g}$, minerals like Calcium, Phosphorus and Iron of fruits, alkaloid capsaicin/capsicutin $\left(\mathrm{C}_{18} \mathrm{H}_{27} \mathrm{NO}_{3}\right)$ and red pigment Capsanthin $\left(\mathrm{C}_{40} \mathrm{H}_{56} \mathrm{O}_{3}\right)$. The crop is grown throughout the world including tropics, subtropics and temperate regions (Pickersgill, 1997) ${ }^{[20]}$. As per latest statistics it is grown over an area of 791 thousand hectares with an average production of 1888 thousand metric tonnes in India (FOA, 2018) ${ }^{[7]}$. In Kashmir it is grown on an area of 3,200 hectares with an annual production of 64,800 tonnes $(\mathrm{NHB}, 2017){ }^{[17]}$. The major chilli growing states of India are Andhra Pradesh, Karnataka, Maharashtra, Orissa, Tamil Nadu, Madhya Pradesh, West Bengal and Rajasthan.

\section{Materials and methods}

The present investigation was conducted in the Experimental Field, Division of Vegetable Science, Sher-e-Kashmir University of Agricultural Science \& Technology of Kashmir, Shalimar, Srinagar during the year 2018. The experimental field is situated within the premises of university campus, about $12.5 \mathrm{~km}$ from main city, at $34^{\circ} \mathrm{N}$ latitude and $74.9^{\circ} \mathrm{E}$ longitude. During the experimentation period the average maximum temperature recorded was $25.3^{\circ} \mathrm{C}$ and the average minimum temperature recorded was $10.9^{\circ} \mathrm{C}$. The total precipitation of 800.8 
mm was received during 2018. The experiment was laid out in Randomized Complete Block Design (RCBD) with three replications. The experimental material consisted of 60 chilli genotypes. The plot size was kept $2.7 \times 1.4 \mathrm{~m}\left(3.78 \mathrm{~m}^{2}\right)$. Each plot consisted of 2 rows of each genotype in each replication at spacing of $45 \times 45 \mathrm{~cm}$. Observations were recorded on twenty quantitative and qualitative parameters viz., plant height $(\mathrm{cm})$, plant spread $(\mathrm{cm})$, number of branches pant ${ }^{-1}$, days to flower initiation, days to fruit initiation, days to harvesting, fruit length $(\mathrm{cm})$, fruit diameter $(\mathrm{cm})$, fruit weight plant $^{-1}(\mathrm{~g})$, fruit pedicel length $(\mathrm{cm})$, fruit pedicel diameter $(\mathrm{cm})$, number of fruits plant ${ }^{-1}$, fruit yield plant ${ }^{-1}$, fruit yield hectare $^{-1}$, dry matter content $(\%)$, vitamin $\mathrm{C}$ content $(\mathrm{mg} / 100 \mathrm{~g})$, capsaicin content $(\mathrm{mg} / \mathrm{g})$, capsanthin content (ASTA units), total phenols (mg/100g) and instrumental colour $\left(\mathrm{L}^{*}, \mathrm{a}^{*}, \mathrm{~b}^{*}\right)$ to study the magnitude of genetic variability existing in the experimental material under study. Five competitive plants were selected at random from each replication and tagged for recording the biometrical observations.

Genotypic coefficient of variation and phenotypic coefficient of variation were computed by the method of Burton and Devane. Heritability (broad sense) were worked by methods followed by Johnson et al and Hanson et al. Genetic advance (GA) and genetic advance as a percent over mean (GAM) were worked by following the methods suggested by Lush and Johnson et al.

\section{Results and discussion}

The analysis of variance was computed to test significant difference among genotypes studied. The mean sum of squares due to various sources for different character are presented in (Table-1). The genotypic and phenotypic coefficient of variability, heritability and genetic advance as percent over mean for each of the characters are presented in (Table-2).

High heritability with high GAM was recorded for most of growth as well as yield characters including., plant height, plant spread, number of branches plant ${ }^{-1}$, fruit length, fruit weight, number of fruits plant ${ }^{-1}$, fruit yield plant ${ }^{-1}$, vitamin $\mathrm{C}$ content at green stage, capsaicin content, capsanthin content, days to flower initiation, indicating the predominance of additive gene components in governing these traits. Thus, there is ample scope for improving these characters based on direct selection from the genetic stock studied.

The difference between the genotypic coefficient of variation (GCV) and phenotypic coefficient of variation (PCV) were found to be narrow for most of the characters. The results suggest that these traits are least affected by environment and selection for these traits on phenotype would be rewarding. For rest of the characters, the estimates of PCV were greater than GCV. This indicates that the variation for these traits is not only by genotypes but also due to environment. Selection based on phenotype may not be rewarding as their expression depends more on environmental factors. Similar observations were reported in chilli by Farhad et al. (2008), Patel et al. (2009), Gupta et al. (2009), Chattopadhyay et al. (2011),
Zehra (2014), Janaki et al. (2015), Pandiyaraj et al. (2017) Jogi et al. (2017), Ain (2018) [6,19,8,4,26,10, 18,11,1].

Heritability (b.s.) estimates were high for almost all the characters and ranged from 65 to 100 per cent indicating that the characters were less influenced by environmental effects and the characters are effectively transmitted to the progeny, suggesting major role of genetic constitution in the expression of a character and thus selection based on phenotypic expression could be relied upon. Similar results were observed by Ain (2018) ${ }^{[1]}$. High heritability was observed for number of fruits plant $^{-1}$, fruit length, fruit diameter, fruit weight, number of fruits plant, and fruit yield plant ${ }^{-1}$. This is in accordance with the findings of Smitha and Basavaraja

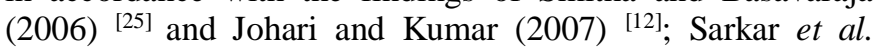
(2009) ${ }^{[23]}$ for number of fruits plant ${ }^{-1}$, number of branches plant $^{-1}$, plant height, length of fruit and fruit yield plant ${ }^{-1}$, Ibrahim et al. (2001) [9]; Rathod et al. (2002) ${ }^{[22]}$, Smitha and Basavaraja (2006) ${ }^{[25], ~ K r i s h n a ~ e t ~ a l . ~(2007) ~}{ }^{[14]}$, Janaki et al. (2015) ${ }^{[10]}$, Chakarbarty et al. (2017) ${ }^{[3]}$ for number of fruits plant $^{-1}$ and plant height and Zehra (2014) ${ }^{[26]}$, Ain (2018) ${ }^{[1]}$ for number of fruits plant ${ }^{-1}$, fruit length, fruit diameter, fruit weight, number of fruits plant, and fruit yield plant ${ }^{-1}$; Jogi et al. (2017) ${ }^{[11]}$ for plant spread. High heritability values for these traits indicates that variation observed was mainly under genetic control and was less influenced by environment.

Among quality characters, high heritability estimates were recorded for vitamin $\mathrm{C}$ content, capsaicin content, capsanthin content and total phenol while moderate heritability estimate recorded for fruit diameter. This is consistent with the reports of Ain (2018) ${ }^{[1]}$.

High heritability along with high genetic advance is an important factor for predicting the resultant effect for selecting the best individuals. In the present study, high heritability was accompanied with high values of genetic advance for plant height, plant spread, number of branches plant $^{-1}$, fruit length, fruit weight, number of fruits plant ${ }^{-1}$, fruit yield plant $^{-1}$, vitamin $\mathrm{C}$ content at green stage, capsaicin content, capsanthin content, days to flower initiation, indicating the preponderance of additive gene action in control of these traits. This suggests that real progress in improvement of such traits through selection could be realized. These results are in conformity with several workers viz., Smitha and Basavaraja (2006) ${ }^{[25]}$ for days to flower initiation; Johnson et al. (1955) ${ }^{[13]}$ and Arya and Saini (1977)

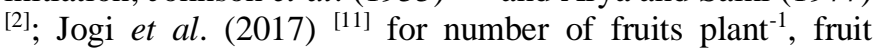
weight, fruit length and fruit yield plant ${ }^{-1}$; Munshi and Behera (2000) ${ }^{[16]}$; Manju and Sreelathkumary (2004) ${ }^{[15]}$ for vitamin C and capsaicin content; Chattopadhhyay et al. (2011) ${ }^{[4]}$ for vitamin C.

Fruit yield is an important character, which decides the commercial viability of the hybrid/variety. Thus the trait deserves the highest priority in any breeding programme. High heritability along with high genetic gain as per cent of mean for this trait suggested the possibility of selecting high yielding cultivars from the present collection. This was supported by Patel et al. $2009^{[19]}$; Sharma et al. $2010^{[24]}$.

Table 1: Analysis of Variance for various traits in chilli (Capsicum annuum L.)

\begin{tabular}{|c|c|c|c|c|c|c|c|c|c|c|c|c|}
\hline $\begin{array}{l}\text { S. } \\
\text { No. }\end{array}$ & $\begin{array}{l}\text { Source of } \\
\text { variation }\end{array}$ & d.f & $\begin{array}{c}\text { Plant } \\
\text { height }(\mathrm{cm})\end{array}$ & $\begin{array}{c}\text { Plant } \\
\text { spread }(\mathrm{cm})\end{array}$ & $\begin{array}{c}\text { No. of } \\
\text { branches } \\
\text { plant }^{-1}\end{array}$ & $\begin{array}{c}\text { Days to flower } \\
\text { initiation }\end{array}$ & $\begin{array}{l}\text { Days to fruit } \\
\text { initiation }\end{array}$ & $\begin{array}{c}\text { Days to } \\
\text { harvesting }\end{array}$ & $\begin{array}{c}\text { Fruit } \\
\text { length } \\
\text { (cm) }\end{array}$ & $\begin{array}{c}\text { Fruit } \\
\text { diameter } \\
(\mathbf{c m})\end{array}$ & \begin{tabular}{c|} 
Fruit \\
weight $(g)$
\end{tabular} & $\begin{array}{l}\text { Fruit pedicel } \\
\text { length }(\mathbf{c m})\end{array}$ \\
\hline 1. & Replication & 2 & 8.23 & 1.94 & 2.46 & 0.31 & 0.05 & 0.43 & 0.50 & 0.01 & 0.05 & 0.23 \\
\hline 2. & Genotype & 59 & $233.53 * *$ & $304.79 * *$ & $223.61 * *$ & $45.58 * *$ & $29.81 * *$ & $393.69 * *$ & $18.57 * *$ & $0.11^{* *}$ & $11.83^{* *} *$ & $1.31 * *$ \\
\hline 3. & Error & 118 & 1.04 & 0.80 & 0.21 & 0.04 & 0.03 & 0.05 & 0.19 & 0.01 & 0.01 & 0.09 \\
\hline
\end{tabular}

*Significant at 0.05 probability level

**Significant at 0.01 probability level 
Table 1: contd...

\begin{tabular}{|c|c|c|c|c|c|c|c|c|c|c|c|c|c|c|}
\hline $\begin{array}{l}\text { S. } \\
\text { No. }\end{array}$ & $\begin{array}{l}\text { Source of } \\
\text { variation }\end{array}$ & d.f & \begin{tabular}{|c|}
$\begin{array}{c}\text { Fruit } \\
\text { pedicel } \\
\text { diameter } \\
(\mathrm{cm})\end{array}$ \\
\end{tabular} & $\begin{array}{l}\text { No. of } \\
\text { fruits } \\
\text { plant }^{-1}\end{array}$ & $\begin{array}{c}\text { Fruit yield } \\
\text { plant }^{-1}(g)\end{array}$ & $\begin{array}{c}\text { Fruit } \\
\text { yield ha } \\
\text { (q) }\end{array}$ & $\begin{array}{c}\text { Dry } \\
\text { matter } \\
\text { content } \\
(\%)\end{array}$ & $\begin{array}{c}\text { Vitamin C } \\
\text { (green) } \\
\left(\mathrm{mg100g}^{-1}\right)\end{array}$ & $\begin{array}{c}\text { Capsaicin } \\
\text { content } \\
\left(\mathrm{mg} \mathrm{g}^{-1}\right)\end{array}$ & $\begin{array}{c}\text { Capsanthin } \\
\text { content } \\
\text { (ASTA } \\
\text { units) } \\
\end{array}$ & $\begin{array}{c}\text { Total } \\
\text { phenol } \\
\left(\mathrm{mg100}^{-1} \mathrm{~g}\right)\end{array}$ & $\begin{array}{c}\text { Instrumental } \\
\text { Colour L* }\end{array}$ & $\begin{array}{c}\text { Instrumental } \\
\text { colour a }\end{array}$ & $\begin{array}{c}\text { Instrumental } \\
\text { colour b }\end{array}$ \\
\hline 1. & Replication & 2 & 0.00 & 3.27 & 155.46 & 1.92 & 1.34 & 2.06 & 0.00 & 42.81 & 0.02 & 2.89 & 3.20 & 3.42 \\
\hline 2. & Genotype & 59 & $0.00 * *$ & $11.83^{* * *}$ & 76217.91 *** & $7822.44 * *$ & $76.41 * *$ & $6450.12 * *$ & $0.03 * *$ & $778.20 * *$ & $1.38 * *$ & $36.64 * *$ & $31.03 * *$ & $2.74 * *$ \\
\hline 3. & Error & 118 & 0.00 & 0.01 & 259.49 & 1.58 & 0.07 & 0.46 & 0.00 & 24.62 & 0.00 & 0.47 & 4.55 & 0.17 \\
\hline
\end{tabular}

*Significant at 0.05 probability level

** Significant at 0.01 probability level

Table 2: Estimates of mean, range, phenotypic variance, genotypic variance, phenotypic and genotypic coefficients of variation for various quantitative and qualitative characters in chilli (Capsicum annuum L.)

\begin{tabular}{|c|c|c|c|c|c|c|c|c|c|}
\hline $\begin{array}{c}\text { S. } \\
\text { No. }\end{array}$ & Parameters & Mean & Range & \begin{tabular}{|c|} 
Phenotypic \\
variance \\
$(\mathbf{P V})$
\end{tabular} & $\begin{array}{c}\begin{array}{c}\text { Genotypic } \\
\text { variance } \\
(\mathbf{G V})\end{array} \\
\end{array}$ & $\begin{array}{c}\text { Phenotypic } \\
\text { coefficient of } \\
\text { variation (PCV) }\end{array}$ & \begin{tabular}{|c|} 
Genotypic \\
coefficient of \\
variation (GCV)
\end{tabular} & $\begin{array}{c}\mathbf{H}^{2} \\
\text { (broad } \\
\text { sense) }\end{array}$ & $\begin{array}{c}\text { Genetic gain } \\
\text { (Genetic advance } \\
\text { as\% of mean) }\end{array}$ \\
\hline 1. & Plant height $(\mathrm{cm})$ & 63.83 & $49.16-86.00$ & 78.53 & 77.49 & 13.88 & 13.79 & 0.98 & 28.21 \\
\hline 2. & Plant spread $(\mathrm{cm})$ & 64.22 & $44.33-86.64$ & 102.13 & 101.33 & 15.73 & 15.67 & 0.99 & 32.15 \\
\hline 3. & No. of branches plant ${ }^{-1}$ & 34.08 & $14.26-48.93$ & 74.68 & 74.46 & 25.35 & 25.32 & 0.99 & 52.08 \\
\hline 4. & Days to flower initiation & 34.78 & $24.40-38.60$ & 15.22 & 15.18 & 11.21 & 11.20 & 0.99 & 23.04 \\
\hline 5. & Days to fruit initiation & 46.05 & $31.40-46.53$ & 9.96 & 9.92 & 7.28 & 7.27 & 0.99 & 14.95 \\
\hline 6. & Days to harvesting & 117.26 & $102.40-134.66$ & 131.27 & 131.212 & 9.77 & 9.76 & 0.99 & 20.11 \\
\hline 7. & Fruit length $(\mathrm{g})$ & 12.27 & \begin{tabular}{|l|}
$7.00-16.07$ \\
\end{tabular} & 6.32 & 6.12 & 20.49 & 20.16 & 0.96 & 40.89 \\
\hline 8. & Fruit diameter $(\mathrm{cm})$ & 1.08 & $0.78-1.92$ & 0.04 & 0.03 & 20.37 & 16.82 & 0.68 & 28.61 \\
\hline 9. & Fruit weight $(\mathrm{g})$ & 5.13 & $1.38-9.28$ & 3.95 & 3.94 & 38.73 & 38.67 & 0.99 & 79.53 \\
\hline 10. & Fruit pedicel length $(\mathrm{cm})$ & 4.75 & $2.10-6.01$ & 0.50 & 0.40 & 14.87 & 13.38 & 0.80 & 24.79 \\
\hline 11. & Fruit pedicel diameter $(\mathrm{cm})$ & 0.28 & $0.21-0.44$ & 0.00 & 0.00 & 15.03 & 13.40 & 0.79 & 24.60 \\
\hline 12. & No. of fruits plant ${ }^{-1}$ & 54.31 & $29.66-99.86$ & 291.69 & 291.13 & 31.44 & 31.41 & 0.99 & 64.64 \\
\hline 13. & Fruit yield/ plant(g) & 276.14 & $59.10-759.52$ & 25578.97 & 25319.47 & 57.91 & 57.62 & 0.99 & 118.09 \\
\hline 14. & Fruit yield $\left(\mathrm{q} \mathrm{hec}^{-1}\right)$ & 90.64 & $23.90-239.43$ & 2608.53 & 2606.95 & 56.34 & 56.32 & 0.99 & 115.99 \\
\hline 15. & Dry matter content $(\%)$ & 79.58 & $61.54-86.07$ & 25.52 & 25.44 & 6.34 & 6.33 & 0.99 & 13.03 \\
\hline 16. & $\begin{array}{c}\text { Vitamin C content at green stage } \\
(\mathrm{mg} / 100 \mathrm{~g})\end{array}$ & 133.00 & $43.86-201.16$ & 2150.34 & 2149.88 & 34.86 & 34.86 & 0.99 & 71.80 \\
\hline 17. & Capsaicin content $(\mathrm{mg} / \mathrm{g})$ & 0.53 & $0.29-0.75$ & 0.01 & 0.01 & 20.21 & 20.04 & 0.98 & 40.95 \\
\hline 18. & Capsanthin content (ASTA units) & 96.03 & $66.24-125.83$ & 275.821 & 251.19 & 17.29 & 16.50 & 0.91 & 32.44 \\
\hline 19. & Total phenol(mg/100g) & 6.41 & $4.90-7.70$ & 0.46 & 0.45 & 10.63 & 10.56 & 0.98 & 21.59 \\
\hline 20. & Instrumental colour $\mathrm{L}^{*}$ & 41.18 & $35.22-50.11$ & 12.53 & 12.05 & 8.59 & 8.43 & 0.96 & 17.03 \\
\hline 21. & Instrumental colour a & 36.82 & $30.78-45.26$ & 13.38 & 8.82 & 9.93 & 8.06 & 0.65 & 13.49 \\
\hline 22. & Instrumental colour b & 15.84 & $14.34-18.58$ & 1.03 & 0.85 & 6.41 & 5.83 & 0.82 & 10.93 \\
\hline
\end{tabular}

\section{References}

1. Ain QU. Msc. thesis submitted to Division of Vegetable Science, SKUAST-Kashmir, Shalimar, Srinagar, 2018.

2. Arya PS, Saini SS. Variability studies in salad type peppers. Prog. Horticuture. 1977; 9(1):37-42.

3. Chakrabarty S, Islam AKMA. Selection criteria for improving yield in chilli (Capsicum annum L.). Advances in Agriculture Article ID 5437870, 2017, 9p.

4. Chattopadhyay A, Sharangi AB, Dai NS, Dutta S. Diversity of genetic resources and genetic association analysis of green and dry chillies of eastern India. Chilean Journal of Agricultural Research. 2011; 71(3):350-356.

5. El-Ghoraba AH, Javed Q, Anjum FM, Hamed SF, Shaabana HA. Pakistani bell pepper (Capsicum annuum L.): Chemical compositions and its antioxidant activity. International Journal of Food Properties. 2013; 16(1):1832.

6. Farhad M, Hasanuzzaman M, Biswas BK, Azad AK, Arifuzzaman M. Reliability of Yield Contributing Characters for Improving Yield Potential in Chilli (Capsicum annum). Int. J. Sustain. Crop Prod. 2008; 3(3):30-38.

7. Foastat. http://www.faostat.org/food and agriculture organisation, United Nations, Rome, 2018.

8. Gupta MA, Singh D, Kumar A. Genetic variability, genetic gain and correlation in chilli (Capsicum annuum L.). Indian J. Agric. Sci. 2009; 79(3):221-223.

9. Ibrahim M, Ganigar VM, Yenjerappa ST. Genetic variability, heritability, genetic gain and correlation studies in chilli. Karnataka Journal of Agricultural Sciences. 2001; 14:784-878.

10. Janaki M, Naidu N. Assessment of genetic variability, heritability and genetic gain for quantitative traits in chilli (Capsicum annuum L.). The Bioscan. 2015; 10(2):729733.

11. Jogi MY, Madalageri MB, Mallimar M, Bawoor S, Mangi V, Porika H. Genetic variability studies in chilli (Capsicum annuum L.) for growth and early yield. International Journal of Pure Applied Bioscience. 2017; $5(5): 858-862$.

12. Johari S, Kumar V. Studies of combining ability, variability, heritability and genetic gain for yield and its attributes in bell pepper (Capsicum annuиm L.). Vegetable Science. 2007; 34(1):103-105.

13. Johnson HW, Robinson HF, Comstock RE. Estimation of genetic and environmental variability in soybean. Agronomy Journal. 1955; 47:477-483.

14. Krishna C, Madalageri MB, Patil MP, Kotlkal YK. Variability Studies in Green Chilli (Capsicum annuum L.). Karnataka Journal of Agricultural Sciences. 2007; 20(1):102-104.

15. Manju PR, Sreelathakumary I. Genetic divergence in hot chilli (Capsicumchinense Jacq.). Capsicum and Eggplant Newsl, 2004, 69-72.

16. Munshi AD, Behera TK. Genetic variability, heritability and genetic gain for some traits in chillies (Capsicum annuum L.). Vegetable Science. 2000; 27(1):39-41.

17. National Horticulture Board, Data Base of Horticultural crops. Gurgaon, New Delhi, 2017. 
18. Pandiyaraj P. Genetic variability, heritability and genetic gain for quantitative and qualitative traits in chilli (Capsicum annuum L.). International Journal of Agriculture Sciences. 2017; 9(14):4081-4083.

19. Patel PN, Fougat RS, Sasidharan N. Studies on genetic variability, correlation and path analysis in chillies (Capsicum annuum L.). Research on Crops. 2009; 10(3):626-631.

20. Pickersgill B. Genetic resources and breeding of Capsicum spp. Euphytica. 1997; 96:129-133.

21. Pujar UU, Tirakannanavar S, Jagadeesha RC, Gasti VD, Sandhyarani N. Analysis of genetic divergence in Chilli (Capsicum annum L.) genotypes. International journal pure applied biosciences. 2017; 5(5):503-508.

22. Rathod RP, Deshmukh DT, Ghode PB, Gonge VS. Correlation and path analysis studies in chilli (Capsicum annuum L.). Haryana Journal of Horticulture Science. 2002; 31(1-2):141-143.

23. Sarkar S, Murmu D, Chattopadhyay A, Hazra P. Genetic variability, correlation and path analysis of some morphological characters in chilli. Journal of Crop and Weed. 2009; 5(1):162-166.

24. Sharma VK, Semwal CS, Uniyal SP. Genetic variability and character association analysis in bell pepper (Capsicum annuum L.). Journal of Horticulture and Forestry. 2010; 2(3):58-65.

25. Smitha RP, Basavaraja N. Variability and correlation studies in chilli (Capsicum annuum L.). Karnataka Journal of Agricultural Sciences. 2006b; 19(4):888-891.

26. Zehra SB. Msc. thesis submitted to Division of Vegetable Science, SKUAST-Kashmir, Shalimar, Srinagar, 2014. 